\title{
ステンレス金網を用いたラップエ具によるラッピング性能* 一金属短織維含有ラップエ具の最道化一
}

\author{
川波多裕司 ${ }^{* * * * *}$ 桐野宙治** 張 宇 ${ }^{* * *}$ 谷 泰弘*** \\ Lapping Performances of a Stainless Steel Mesh Lap \\ - Optimization of the Composite Lap Between Compressed Short Metal Fibers and Epoxy Resin-
}

Yuji KAWAHATA, Okiharu KIRINO, Yu ZHANG and Yasuhiro TANI

\begin{abstract}
In a rough lapping process of substrates made of $\mathrm{SiC}$ or sapphire, a cast-iron lap is generally used. However, the cast-iron lap has some problems, which it has low corrosion resistance and low removal rate. We developed a fiber lap as an alternative lapping tool for solving these problems. The fiber lap is a tool containing stainless-steel fibers in the epoxy resin. A stainless-steel mesh (called as a "mesh lap") was used as a lapping tool to optimize the dimensions of the fibers. As a result, the removal rate of the mesh lap was very high compared with the cast-iron lap. Then, the lapping mechanism on which a high removal rate could be obtained was investigated. The lapping performances of the mesh lap can be changed depending on the wire diameter and the pitch interval. The difference in the lapping performances was examined by observing the moving behavior of the abrasive grains on the tool. It was found that there were two types of abrasive-grain behaviors, meandering motion and linear motion. Finally, by reflecting the results obtained using the mesh lap on the fiber lap, we improved the lapping performances of a fiber lap.
\end{abstract}

Key words: mesh, lapping tool, sapphire, removal rate, surface finish, tool wear rate, epoxy resin, fiber, stainless steel

\section{1. 緒言}

近年, IoT 市場は年々拡大し続け 2022 年には 3.2 兆円規模に なると予想されている. これに伴い半導体デバイスの需要も高 まっており, その中でも高性能なパワー半導体が注目されてい る ${ }^{1}$. また省エネルギーの観点から発光ダイオードも注目されて おり, これらの基板材料には, サファイアや $\mathrm{SiC}, \mathrm{GaN}$ といっ た高硬度でかつ化学的にも非常に安定した難削材が用いられて いるため, その製造工程では多くの工数と時間が必要となり, これが価格上昇につながり, それらの材料の普及の妨げとなっ ている ${ }^{2)}$. それらのラッピング工程では, 一般的に工具として鋳 鉄定盤が用いられているが，加工能率が低いことや錆びやすく 扱いにくいことが問題となっている ${ }^{3)}$. 我々のグループでは, そ れらの問題点を解決するラップ工具として金属短繊維の圧縮体 にエポキシ樹脂を含有させた繊維定盤の開発を行っている ${ }^{4}$. 繊 維定盤は, 含有させる繊維の形状により研磨性能が変化すると 考えられ, その研磨性能一の影響を把握するためにワイヤ径と ピッチ間隔を容易に変更が可能なステンレス鋼の金網(以下, メ ッシュ工具と称する)をラップ工具として用いて実験を行った. 具体的なメッシュ工具を示寸場合は, メッシュ工具の前にメッ シュ番号を付記した.

本研究では, メッシュ工具を用いて実験を行った結果, メッ シュ工具が非常に高い研磨性能を示すことが判明したため, そ の研磨メカニズムの解明を試みた. まずメッシュ工具の摩耗に よる工具表面の変化が研磨性能に与える影響を調べた. 次にワ イヤ径やピッチ間隔の差異が研磨性能に与える影響を調べ，そ の研磨性能の違いを工具上の砥粒の挙動を観察することで検討

\footnotetext{
* 原稿受付 平成 30 年 6 月 13 日 揭载決定 平成 30 年 9 月 30 日

** 正 会 員 株式会社クリスタル光学(滋賀県大津市今堅 田 3-4-25)

*** 正 会 員 立命館大学(滋贺県草津市野路東 1-1-1)
}

した. 最後にそれらの結果を繊維定盤に反映させ, 繊維定盤の 研磨性能の向上を試みた結果を報告する.

\section{2. 実験装置の概要および実験方法}

鋳鉄定盤と瀻維定盤の 2 種類のラップ工具と, ワイヤ径とピ ッチ間隔の異なる 3 種類のメッシュ工具を用いて実験を行った. 鋳鉄定盤には, 一般にラッピング工程で用いられている球状黒 鉛鋳鉄定盤(FCD450)を用いた. 繊維定盤には, 前報 ${ }^{4)}$ で最も性 能の良かった直径 $50 \mu \mathrm{m}$ で長さが $1 \mathrm{~mm}$ の金属繊維を $40 \mathrm{vol} \%$ 含有させたものを使用した. メッシュ工具には, ワイヤの材質 がステンレス鋼 SUS304 の平織の金網を用いた. 平織とは, 縦と 横のワイヤを 1 本ずつ交互に縫い合わせた織り方である. メッ シュ工具の材質にステンレス鋼を選定したのは, 鋳鉄定盤の錆 びの問題を解決する目的で繊維定盤にステンレス鋼の繊維を用 いており，同材質で実験を行うためである.

鋳鉄定盤と繊維定盤は, 定盤表面をノーズ半径 $0.4 \mathrm{~mm}$ の超 硬合金の切削バイトを用いて, 切込み $15 \mu \mathrm{m}$, 工具送り速度 13 $\mathrm{mm} / \mathrm{min}$, 定盤回転数 $60 \mathrm{rpm}$ の条件でフェーシングを行った. その後粒度 $\# 100$ のダイヤモンド電着ドレッサを用いて, 加工圧 力 $15 \mathrm{kPa}$, 定盤回転数 $60 \mathrm{rpm}$, 電着ドレッサ回転数 $60 \mathrm{rpm}$ の条 件で, 純水を $25 \mathrm{~mL} / \mathrm{min}$ で供給しながらドレッシングを 10 分間 行うことで, 砥粒の保持性が高められるといわれる, 使用砥粒 の平均粒径(理研コランダム社検査值 $20 \mu \mathrm{m}$ ) の約 3 分の 1 とな る約 $5.7 \sim 6.0 \mu \mathrm{mRa}$ の粗さに定盤表面を調整した. メッシュ工 具には, ステンレス鋼製の定盤にメッシュを接着剤により貼り 付けたものを実験に用いた. 工作物中央まで砥粒が供給される ように, 鋳鉄定盤には表面に幅 $2 \mathrm{~mm}$, 深さ $5 \mathrm{~mm}$ の矩形㴖を $20 \mathrm{~mm}$ 間隔で格子状に掘った定盤を用いた. 繊維定盤の表面の 凹凸形状とメッシュ工具の織目の穴(以下，目開きと称する)が スラリーの供給溝の役割を果たすため, この 2 種類のラップエ 具では溝加工を行わなかった. 
Case of observing the abrasive-grain behavior

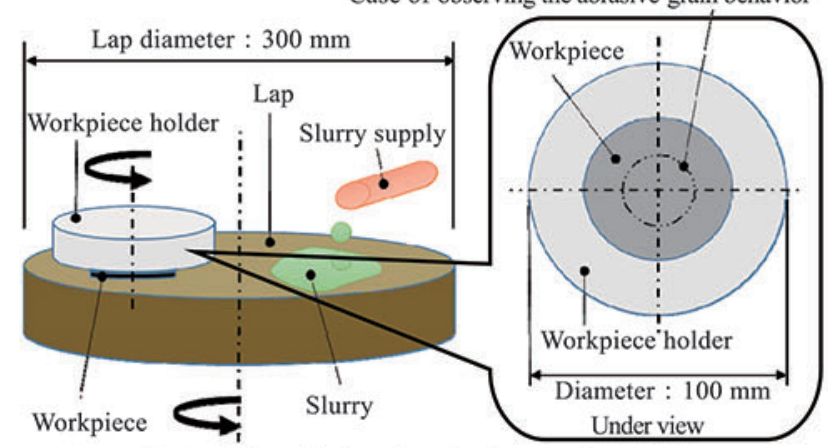

Fig.1 Schematic view of our lapping experiment

Table 1 Experimental conditions

\begin{tabular}{l|l}
\hline Machine & $\begin{array}{l}\text { Single-sided lapping machine } \\
\text { (Engis Japan Corp., EJW-400IFN) }\end{array}$ \\
\hline Lap & Cast-iron lap, Fiber lap, Mesh lap \\
\hline Lap diameter & $300 \mathrm{~mm}$ \\
\hline Workpiece & $\begin{array}{l}\text { Sapphire wafer (C-plane) } \\
\varnothing 50.8 \mathrm{~mm}(2 \text { inches }) \times 1 \mathrm{mmt} \times 1 \text { sheet } \\
\end{array}$ \\
\hline Prefinish $2 \mathrm{nmRa}$
\end{tabular}

図 1 および表 1 に研磨実験の様子および研磨条件を示す.メ ッシュ工具では, ワイヤ径とピッチ間隔により研磨性能が変化 すると予想されたため, 目開きを約 $0.1 \mathrm{~mm}$ ずつ変化させた, ワイヤ径 $0.29 \mathrm{~mm}$ の 40 メッシュ工具(目開き $0.345 \mathrm{~mm}$ ), ワ イヤ径 $0.18 \mathrm{~mm}$ の 60 メッシュ工具(目開き $0.243 \mathrm{~mm}$ ), ワイ ヤ径 $0.1 \mathrm{~mm}$ の 100 メッシュ工具(目開き $0.154 \mathrm{~mm}$ )の 3 種類 を実験に用いた. 研磨機には, 実験状態の安定のため工作物の 強制回転が可能な定盤直径 $300 \mathrm{~mm}$ の片面ラッピング装置を用 いた. 加工圧を $20 \mathrm{kPa}$ とし工具回転速度を $71 \mathrm{~m} / \mathrm{min}$, 工作物回 転速度を $19 \mathrm{~m} / \mathrm{min}$ とした.

工作物には厚み $1 \mathrm{~mm}$ の 2 インチのサファイア基板(C 面)を 1 枚用い, 図 1 に示すように工作物保持具の中心に直径 2 インチ $(+0.3 \mathrm{~mm})$ の深さ $0.6 \mathrm{~mm}$ の穴を加工し, その穴の中にスピン を許容するために工作物を水貼りで固定した. 前加工面の凹凸 形状が研磨特性に与える影響を抑制するため, 工作物はラッピ ング研磨機でダイヤモンド砥粒(ダイヤマテリアル社製, 平均粒 径 $1 \mu \mathrm{m}$ )を用いて, 前加工面を $2 \mathrm{nmRa}$ の鏡面に調整した. ス ラリーにはサファイア基板の粗加工に多用されている GC\#600 砥粒を，3wt\%の濃度で純水に加えたものを $25 \mathrm{~mL} / \mathrm{min}$ の流量で かけ流しで実験を行った.

実験は 1 条件につき 3 回行い, 研磨能率と工具摩耗速度の平 均值を実験值とした. 研磨による除去量は研磨前後の工作物の 重量を電子天秝により測定し, 工作物の比重を用いて厚み変化 量としての 1 分あたりの研磨能率を算出した. 仕上げ面粗さは 光学式表面形状計測装置 (AMETEK 社製, NewView 8300) を用 いて $0.83 \mathrm{~mm} \times 0.83 \mathrm{~mm}$ の領域に対してロバストガウシアン フィルタをかけ, カットオフ值を $0.2 \mathrm{~mm}$ として, エッジから 5 $\mathrm{mm}$ 内側の 90 度毎の 4 筒所と工作物の中心部の計 5 筒所測定し, 算術平均高さ $\mathrm{Sa}$ の平均值を求めた.

工具摩耗速度は，鋳鉄定盤では研磨前後の定盤の厚みを円周

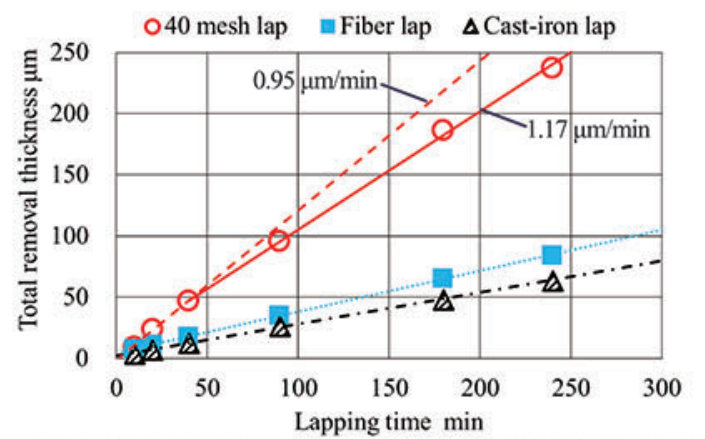

Fig.2 Change of total removal thickness with lapping time using various lapping tools

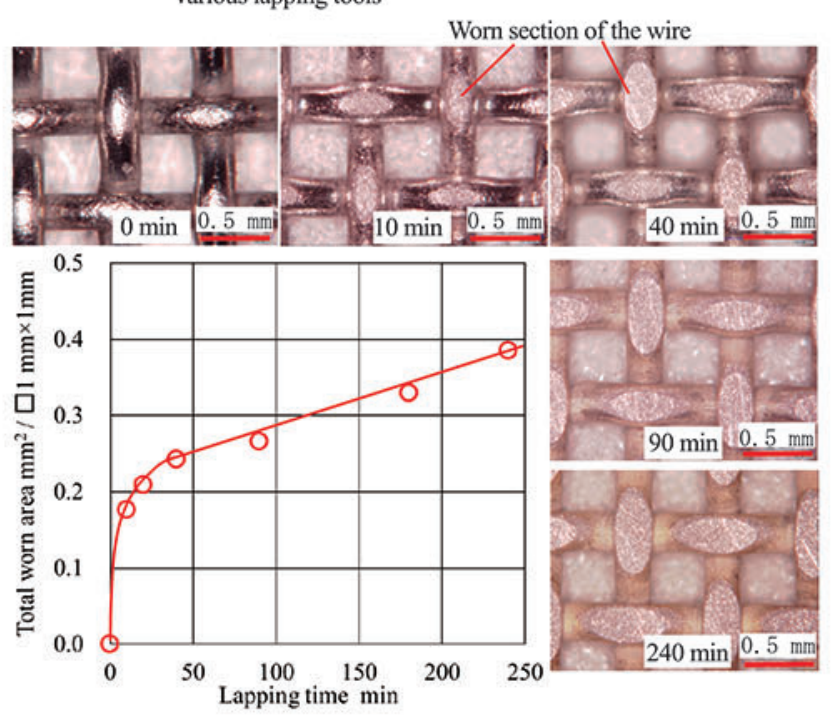

Fig.3 Change of total worn area with lapping time and microscopic images of the worn area in a 40 mesh lap

方向に 30 度毎使用部分の中央部分合計 12 箇所を三次元測定機 （カールツァイス社製 PRISMO7JV VAST）で測定し, メッシュ工 具ではマイクロメータを用いて同じく 12 䇢所測定し, その厚み の差の平均値を算出することで求めた.

\section{3.メッシュ工具の特異性}

\section{1 メッシュ工具による研磨性能の経時変化}

メッシュ工具は縦と横のワイヤを交互に縫い合わせて形成さ れており, 工具摩耗量により研磨に作用する面積が変化すると 考えられる. そこでメッシュ工具の表面状態の変化が研磨性能 に与える影響について調べた. 比較対象として鋳鉄定盤と瀻維 定盤を用いた. 100 メッシュ工具と 60 メッシュ工具では表面状 態の変化が速く, その変化の割合がわかりにくいと予想したた め, メッシュ工具には 40 メッシュ工具を用いた. 研磨時間が 240 分までの累積研磨量の経時変化を図 2 に示す. 鋳鉄定盤と瀻維 定盤では研磨量はほぼ一定の割合で増加している. 一方, 40 メ ッシュ工具では実験開始から 40 分までと 40 分から 240 分まで の研磨能率を比較すると, $1.17 \mu \mathrm{m} / \mathrm{min}$ と $0.95 \mu \mathrm{m} / \mathrm{min}$ となり, 40 分以降では約 $20 \%$ 減少していた.

研磨能率が変化する原因は 40 メッシュ工具の表面状態の変化 にあると考え, マイクロスコープを用いて各研磨時間のワイヤ 摩耗部の面積を測定した. $\square 1.0 \mathrm{~mm} \times 1.0 \mathrm{~mm}$ の領域で確認で きる全てのワイヤ摩耗部の面積を測定し, その総和を総摩耗部 面積とした. 図 3 にワイヤ摩耗部の面積の経時変化と研磨時間 が 0 分, 10 分, 40 分, 90 分, 240 分経過した直後の表面状態を 観察した結果を示す. 実験開始から 40 分までの対数近似曲線と 


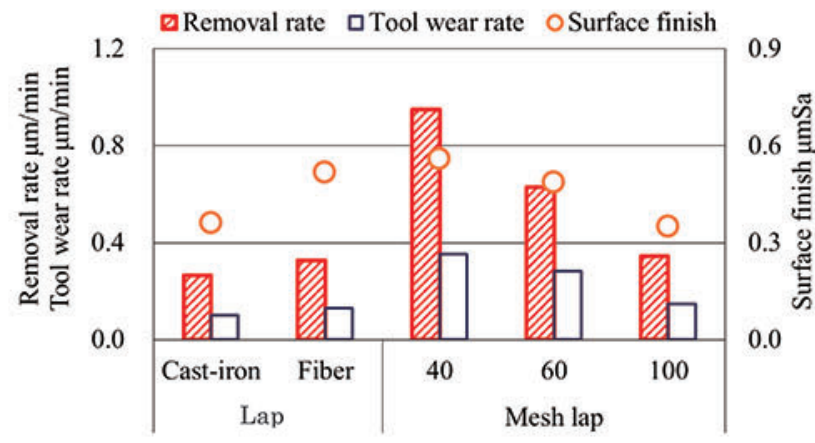

Fig.4 Comparison of lapping characteristics and tool wear rate using various lapping tools

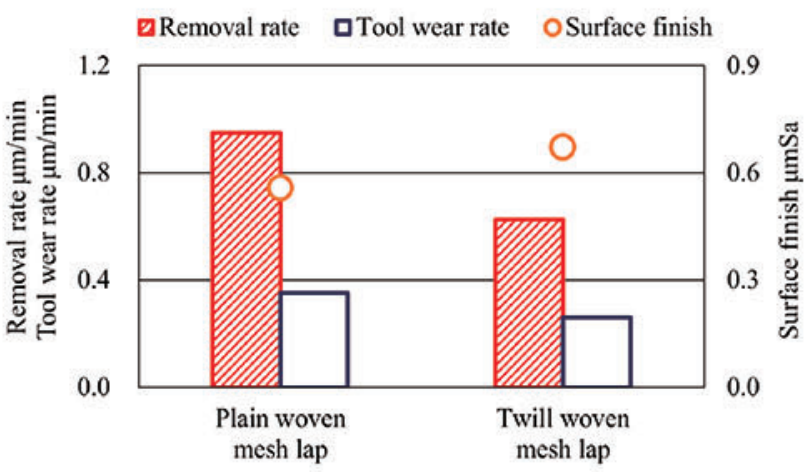

Fig.5 Comparison of lapping characteristics and tool wear rate with different woven mesh laps

40 分から 240 分の近似直線の傾向から実験開始から 40 分までの 方が総摩耗部面積の増加率が大きいことがわかる．そこで研磨 能率としては, 研磨能率が安定した 40 分から 240 分の平均值を 用いた．実験開始時では研磨に作用する面積が小さいため作用 する砥粒が少なくなり仕上げ面粗さが悪化するが，時問経過に 伴い良好になり 90 分以降ではほぼ一定值となる. このことから 240 分間研磨を行うことで到達仕上げ面粗さに達していると考 えられる.

\section{2 各種ラップエ具の研磨性能の比較}

図 4 に鋳鉄定盤と繊維定盤と前述の 3 種類のメッシュ工具の 研磨性能を示す. メッシュ工具の場合は, 鋳鉄定盤よりも仕上 げ面粗さは悪化しているものもあるが, 研磨能率は全て向上し ていることがわかる. 通常のラップ工具では, 作用砥粒数を変 化させるのは難しいが, メッシュ工具ではピッチ間隔で容易に 作用砥粒数を変化させることができる. また 100 メッシュ工具 が鋳鉄定盤よりも仕上げ面粗さが良好で, 研磨能率が約 $23 \%$ 向 上している. この結果から 100 メッシュ工具を基準に目開き等 を変更させて実験を行ったが, 鋳鉄定盤よりも仕上げ面粗さが 良好で研磨能率がこれ以上向上するメッシュ工具を見つけるこ とができなかった．そのため本研究の目的である難削材に対す る研磨時間の短縮に重きをおき, 研磨能率が鋳鉄定盤の約 3 倍 となった 40 メッシュ工具を中心にメッシュ工具の加エメカニズ ムを検討した。

工具摩耗速度を比較すると全てのメッシュ工具で鋳鉄定盤や 繊維定盤より劣っている. メッシュ工具はワイヤを縫い合わせ た構造となっているため, 実験開始時では研磨に作用する面積 が小さく砥粒 1 個あたりにかかる圧力が上昇し, 工具に対する 砥粒の押込み量が増加するため工具摩耗速度が増加すると考え られる. またメッシュ工具はワイヤが 1 層しかないため, 摩耗 によりワイヤが破断すると研磨性能が大幅に減少することを実
Q Removal rate $\square$ Tool wear rate $O$ Surface finish

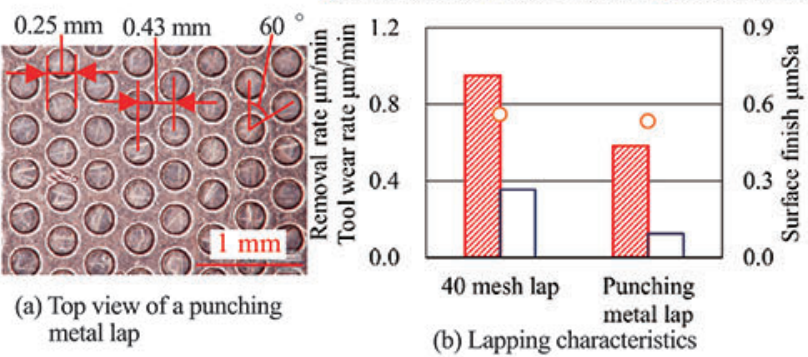

metal lap

(b) Lapping characteristic

Fig.6 Microscopic image of a punching metal lap and comparison of lapping characteristics and tool wear rate using various lapping tools

Table 2 The dimensions of each mesh laps used

\begin{tabular}{|c|c|c|c|c|c|}
\hline Notation & $\begin{array}{c}\text { Mesh } \\
\text { number }\end{array}$ & $\begin{array}{c}\text { Wire diameter } \\
\mathrm{mm}\end{array}$ & Notation & $\begin{array}{c}\text { Mesh } \\
\text { number }\end{array}$ & $\begin{array}{c}\text { Wire diameter } \\
\mathrm{mm}\end{array}$ \\
\hline (1) & \multirow{3}{*}{40} & 0.29 & (8) & \multirow{2}{*}{60} & 0.15 \\
\hline (2) & & 0.26 & (9) & & 0.14 \\
\hline (3) & & 0.22 & (110) & 70 & 0.14 \\
\hline (4) & \multirow{2}{*}{50} & 0.22 & (11) & \multirow{2}{*}{80} & 0.12 \\
\hline (5) & & 0.18 & (12) & & 0.10 \\
\hline (6) & \multirow{2}{*}{60} & 0.19 & (13) & 90 & 0.10 \\
\hline (7) & & 0.18 & (14) & 100 & 0.10 \\
\hline
\end{tabular}

験で確認している. 以上の結果からメッシュ工具は, 工具の耐 摩耗性には劣るが非常に高い研磨性能を示すため, 次章でその 優れた性能が得られる研磨メカニズムの解明を行った.

\section{3 メッシュ工具の織り方の差異による研磨性能の変化}

金網の織り方には平織, 綾織, 酉織の 3 種類があり, 織り方 により研磨性能が変化すると考えられる. そこでメッシュ工具 の織り方の差異による研磨性能の変化について調べた. 曽織に は目開きが無く表面状態が大きく異なるため除外した. 図 4 で 最も研磨能率に優れたワイヤ径 $0.29 \mathrm{~mm}$ の 40 メッシュ工具の 織り方のみが異なる, 綾織のメッシュ工具を用いて表 1 の条件 で実験を行った結果を図 5 に示す. 綾織とは, ワイヤの上を 2 本通過した後 2 本のワイヤの下を通過させることを繰り返した 織り方である. 図 5 の結果から工具摩耗速度は綾織の方が $26 \%$ 減少しているが, 研磨能率は平織の方が $52 \%$ 向上し仕上げ面粗 さも約 $17 \%$ 改善している.この結果から研磨性能に優れる平織 のメッシュ工具を引き続き用いて評価を行うことにした.

\section{4. メッシュ工具での研磨メカニズムの解明}

\section{1 凹部の連続性が研磨性能に与える影響}

メッシュ工具は図 3 の研磨後の表面状態からわかるようにワ イヤ摩耗部が凸部となり，それ以外の部分が凹部となる. その ため凸部の周辺を凹部が囲むような構造になっており，この凹 部の構造も研磨性能に影響を与えていると考えられる. そこで ステンレス鋼の円板に穴を空けたパンチングメタルを用いて比 較実験を行うことで，凹部の連続性の研磨性能への影響を調べ た. パンチングメタルは, 穴が緻密に配列されている方が研磨 性能が向上するため, 容易に入手可能なもので最も穴のピッチ 間隔が狭いパンチングメタルを用いた. 図 6(a)に実験で用いた, チドリに 60 度の角度で $\phi 0.25 \mathrm{~mm}$ の貫通穴を $0.43 \mathrm{~mm}$ 間隔で 穴加工を行ったパンチングメタルの外観を示し, 同図(b)に表 1 の条件で実験を行い, ワイヤ径 $0.29 \mathrm{~mm}$ の 40 メッシュ工具と 比較した結果を示す.

同図(b)から仕上げ面粗さは同等であるが，工具の耐摩耗性は パンチングメタルの方が優れ, 研磨能率は 40 メッシュ工具の方 


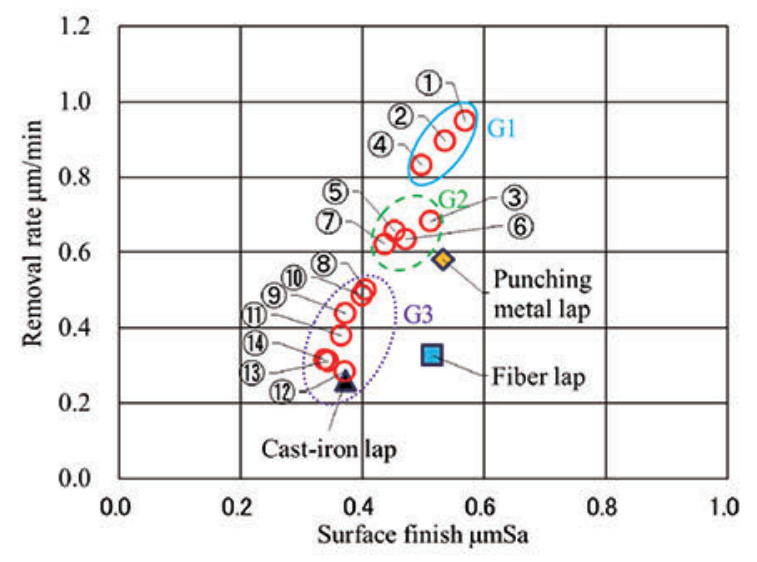

Fig.7 Relationship between surface finish and removal rate using GC\#600 abrasive grains and various lapping tools

が $63 \%$ も高くなっている. 仕上げ面粗さが同等であることから 作用砥粒数は同等であると考えられる. 同等の作用砥粒数で研 磨能率が大きく異なっていることから, 工作物と砥粒の相対速 度に差があるのではないかと考えられる. つまり凹部の形状が パンチングメタルのように単独の穴であるよりもメッシュ工具 のように凸部の周辺を凹部が囲む構造の方が砥粒と工作物の相 対速度を向上させることができるのではないかと予想された.

\section{2 メッシュ工具の研磨性能}

次にメッシュ工具の研磨性能の傾向を把握するために表 2 に示 す 14 種類のワイヤ径とピッチ間隔を変化させたメッシュ工具を 用いて表 1 の条件で実験を行った. ピッチ間隔は1インチ (25.4 $\mathrm{mm}$ )をメッシュ番号で割った值となる. 各メッシュ工具と鋳鉄定 盤と繊維定盤とパンチングメタルの研磨能率と仕上げ面粗さの関 係を図 7 に示す．仕上げ面粗さは，砥粒の切込みが深いほど粗く なり, 砥粒切込み深さと加工圧力を作用砥粒数で割ったものとは 正の相関関係がある. 一定の加工圧力で作用砥粒数が多ければ砥 粒 1 つ当たりにかかる加工圧力は低くなり, 砥粒の切込みは浅く なる.このため仕上げ面粗さは作用砥粒数に反比例する.

一方, 研磨能率は砥粒切込み深さと作用砥粒数と砥粒と工作物 の相対速度の積に比例する. 砥粒切込み深さは上述のような正の 相関関係があるため, 加工圧力が同じ条件下で横軸を仕上げ面粗 さとし縦軸を研磨能率とすると, 同じ仕上げ面粗さで研磨能率が 高い場合, 相対速度が速いということになる. 通常の研磨では, 研磨能率が向上すると砥粒の切込みが梁くなり仕上げ面粗さは悪 化するが, 図 7 から仕上げ面粗さが同等で研磨能率が大きく異な るメッシュ工具が存在することがわかる. このことからワイヤ径 やピッチ間隔の差異により研磨メカニズムが変化していると考え られた. 図 7 の傾向から研磨メカニズムが異なっていると予想し た $3 つ$ 領域を図のように G1, G2, G3にグループ分けした. 各 グループでの研磨メカニズムを詳しく調べるために, 各メッシュ 工具上の砥粒の挙動を調べることにした.

\section{3 メッシュ工具上の砥粒の挙動}

図 1 の工作物保持具の中心に $\phi 30 \mathrm{~mm}$ の貫通穴加工を行 い, 両面が鏡面の 2 インチサファイアを工作物保持具の中 心にワックスで貼り付け, その裹面からサファイアを通し て工具上の砥粒の挙動を高速度カメラ (フォトロン社製 FASTCAM AX200)を用いて観察した. 観察には, 各グルー プに属する G1 のワイヤ径 $0.29 \mathrm{~mm}$ の 40 メッシュ工具(1), G2 のワイヤ径 $0.18 \mathrm{~mm}$ の 60 メッシュ工具(7), G3 のワイ ヤ径 $0.1 \mathrm{~mm}$ の 100 メッシュ工具(14)の 3 種類のメッシュ工

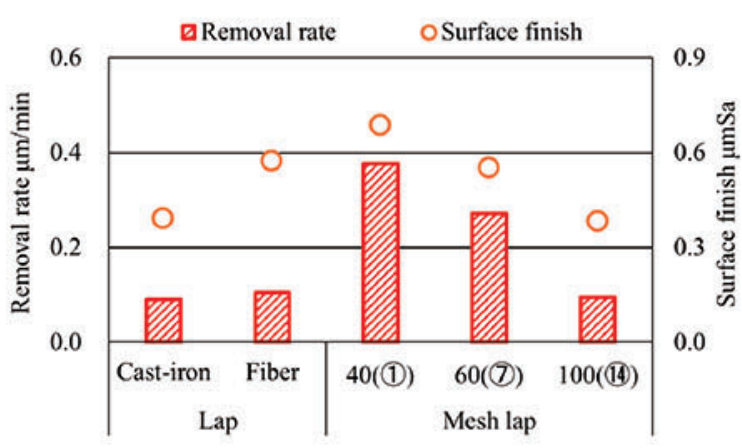

Fig.8 Comparison of lapping performances of various lapping tools under the condition of observing the abrasive-grain behavior

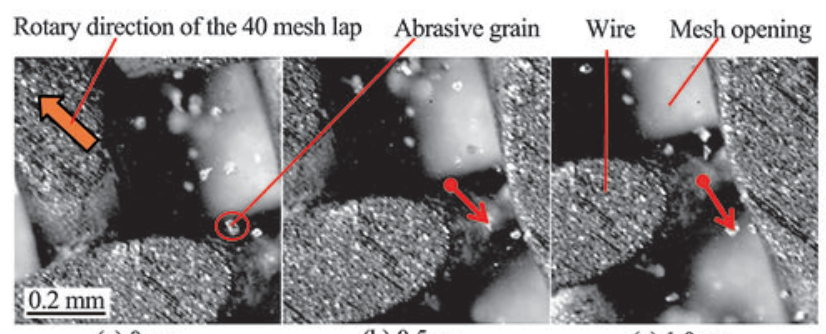

(a) $0 \mathrm{~ms}$ (b) $0.5 \mathrm{~ms}$

(c) $1.0 \mathrm{~ms}$

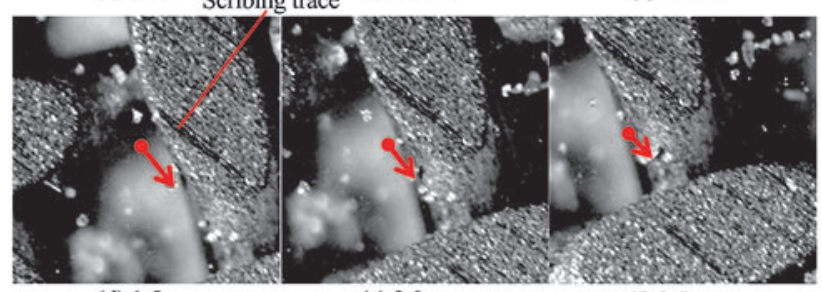

(d) $1.5 \mathrm{~ms}$

(e) $2.0 \mathrm{~ms}$

(f) $2.5 \mathrm{~ms}$

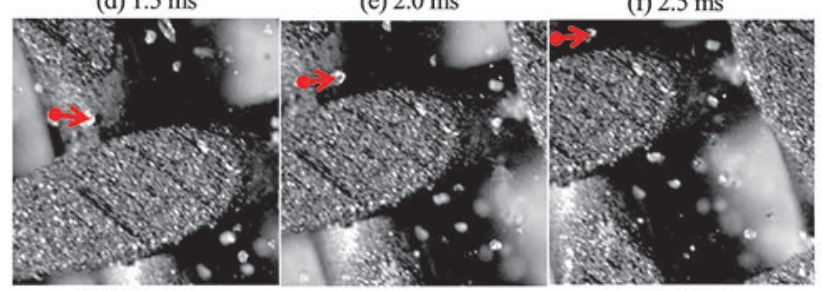

(g) $3.0 \mathrm{~ms}$

(h) $3.5 \mathrm{~ms}$

(i) $4.0 \mathrm{~ms}$

Fig.9 Relative behavior of abrasive grains on a 40 mesh lap (1)

具を用いた. 表 1 の条件で観察を試みたが鮮明な画像が得 られなかったため, 工具回転数を $30 \mathrm{rpm}$, 研磨圧力を $15 \mathrm{kPa}$, スラリー澧度を $1 \mathrm{wt} \%$ で供給量を $5 \mathrm{~mL} / \mathrm{min}$ として, 工作物 を回転させずに観察を行った．観察条件下でもメッシュ工 具の研磨性能の傾向に変化がないことを確認するため, 観 察条件下で 240 分間実験を行った結果を図 8 に示す. 図 8 と図 4 では定性的に同じ研磨性能の傾向が得られているこ とから,この観察条件下でも基本的な研磨メカニズムに変 化はなく, 観察された砥粒の挙動は図 4 の結果に反映され ると考えられる.

図 9 に最も高い研磨能率を示した図 7 で $\mathrm{G} 1$ に属するワイ ヤ径 $0.29 \mathrm{~mm}$ の 40 メッシュ工具(1)上の砥粒を観察した動 画の $0.5 \mathrm{~ms}$ 経過ごとのスナップショットを示す. 同図から 砥粒は, メッシュ工具(1)よりも遅れながら相対的に移動し ており,メッシュ工具(1)上を滑っていることがわかる. そ こで回転しているメッシュ工具(1)を基準とし，メッシュ工 具(1)に対して滑りながら移動する砥粒の軌跡を観察するこ とで砥粒の挙動を把握した. 同図 (a)の赤丸内の砥粒の挙動 に着目し, 各図の矢印は $0.5 \mathrm{~ms}$ 前の画像を現在の画像と重 ね合わせて $0.5 \mathrm{~ms}$ 前の移動系での砥粒の位置を把握し, そ 


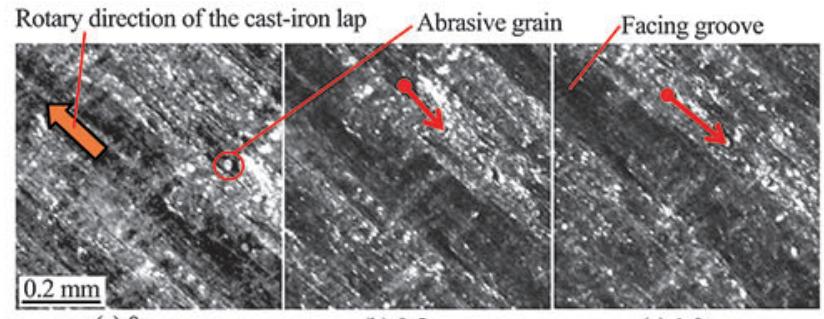

(a) $0 \mathrm{~ms}$

(b) $0.5 \mathrm{~ms}$

(c) $1.0 \mathrm{~ms}$

Fig.10 Relative behavior of abrasive grains on a cast-iron lap

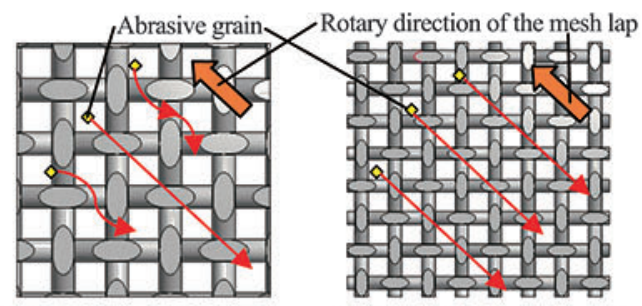

(a) Case of 60 mesh lap (7)

Fig.11 Schematic images of the abrasive-grain behavior on the mesh laps

の位置から現在の砥粒の位置までの移動量を表している. 同図から砥粒はメッシュ工具(1)上のワイヤ摩耗部を避け， 蛇行しながら移動していることがわかる．蛇行する砥粒に は，凸部(ワイヤ摩耗部)のエッジ部に沿いながらエッジ部 で一時的に保持され，また蛇行移動を開始する挙動を繰り 返す砥粒も観察された．ワイヤ摩耗部の表面には工具の回 転方向と同じ方向に傷があり，直線的に移動する砥粒も多 少は存在すると考えられる。しかし撮影した動画ではほと んどの砥粒が蛇行しながら移動しており，直線的に移動す る砥粒は非常に少なかった。

同条件で鋳鉄定盤上の砥粒の観察を行ったスナップショ ットを図 10 に示す. 矢印が示すように工具回転方向に直線 的に移動している砥粒のみが観察され，蛇行する砥粒は観 察されなかった.これらの結果から鋳鉄定盤と 40 メッシュ 工具(1)では砥粒の挙動が異なり，これが研磨性能に大きな 影響を与えたと考えられた。

図 11 に G2 のグループに属するワイヤ径 $0.18 \mathrm{~mm}$ の 60 メッシュ工具(7)と G3 のグループに属するワイヤ径 $0.1 \mathrm{~mm}$ の 100 メッシュ工具(14)の砥粒の挙動の概略図を示す. 同図 (a)の 60 メッシュ工具(7)では, 40 メッシュ工具(1)と同様に ワイヤ摩耗部を避けながら蛇行する砥粒と鋳鉄定盤のよう に工具回転方向に直線的にワイヤ部に乗り上げながら移動 する砥粒の 2 種類が観察された. 同図 (b)の 100 メッシュ工 具(14)では蛇行する砥粒は無く, 直線的に移動する砥粒のみ が観察された. この挙動は鋳鉄定盤に類似しており, 100 メ ッシュ工具(14)と鋳鉄定盤は同じ G3 のグループに属してい ることから，G1 では砥粒は主に蛇行しながら移動し，G2 では蛇行する砥粒と G1 よりも多くの直線的に移動する砥 粒が混在し，G3 では砥粒は主に直線的に移動していると考 えられる.

このような砥粒の挙動の差は, ラップ工具上を直線的に 滑る砥粒の動きを妨害するせき止め効果の差異であると考 えられる，ワイヤ部のせき止め効果が高いほど砥粒は蛇行 しながら移動し, せき止め効果が低いほど直線的に移動す ると考えられる.つまり多くの砥粒を蛇行させることがで きる構造を有したメッシュ工具は，実際に研磨に作用する 砥粒も移動が抑制されるため，砥粒と工作物との相対速度 が速くなることで研磨能率が向上すると考えられる.そこ

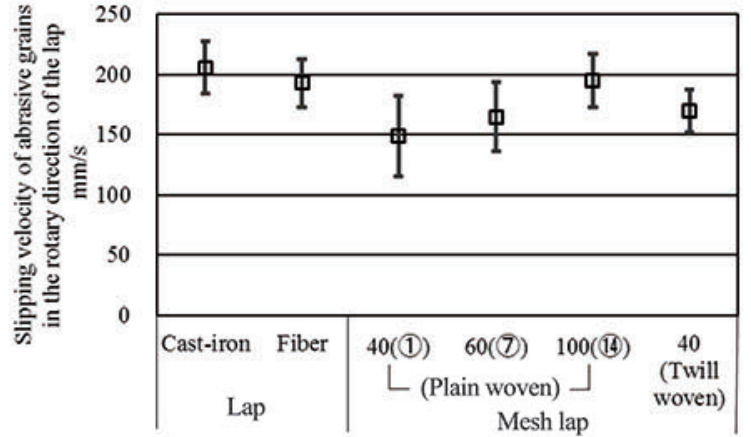

Fig.12 Slipping velocity of abrasive grains on the each laps

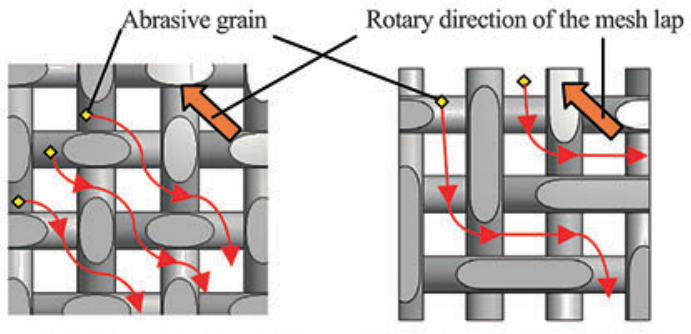

(a) Case of plain woven mesh

(b) Case of twill woven mesh

Fig.13 Schematic images of the abrasive-grain behavior with different woven mesh laps on the 40 mesh laps

で工具回転方向の砥粒の滑り速度成分 (以下, 滑り速度と称 する)を調べた．滑り速度は, 静止状態の工作物に対する工 具回転方向の砥粒の速度成分をラップ工具の理論回転速度 から差し引いた値を表す.フォトロン社製の解析ソフト Photron FASTCAM を用いて, 撮影した動画からラップ工具上 を滑る砥粒を無作為に 30 個選定し, 工具回転方向の砥粒の 速度成分を測定した. ラップ工具の回転速度は, 高速度力 メラを定盤の中心から半径方向に $90 \mathrm{~mm}$ の位置に設置した ため, 理論定盤速度は $283 \mathrm{~mm} / \mathrm{s}$ となる.これに対して同じ 解析ソフトを用いて工具回転方向の速度成分を測定した結 果, 平均值が $281 \mathrm{~mm} / \mathrm{s}$ となったことから正確な測定が行え ていると判断された．各ラップ工具上の砥粒の滑り速度の 平均值と標準偏差を図 12 に示す. 図 12 から蛇行する砥粒 が多いほど砥粒の滑り速度が遅くなることがわかった．ま た同図と図 8 の結果を比較すると砥粒の滑り速度が遅いほ ど研磨能率が向上していることから，せき止め効果が高い ほど蛇行する砥粒が増加し, 滑り速度が遅くなると考えら れる.

また 3.3 節の平織と綾織の 40 メッシュ工具の砥粒の挙動 の概略図を図 13 に示す. 同図 (b) の綾織はワイヤを 2 本ずつ 通して編み込まれているため, 同図(a)の平織に比べて砥粒が方 向を変えるまでの距離が長くなっている.このことから平織に 比べて砥粒のせき止め効果が低くなり, 図 12 に示されるように 砥粒の滑り速度も速くなるため, 図 5 のように研磨能率が減少 したと考えられる.

メッシュ工具では, ワイヤが摩耗しているため凸部(ワイヤ摩 耗部) で研磨が行われると考えられる. 凸部の表面状態から砥粒 の転動または引っ掻きにより研磨が進行していると考えられる が，凸部のエッジ部で保持される砥粒も研磨に寄与していると 考えられる. 実際に凸部のエッジ部を沿いながらエッジ部で一 時的に保持され，また蛇行移動を開始する挙動を繰り返す砥粒 も観察されている.この砥粒は蛇行する砥粒が多いほど多く観 察されており，エッジ部に保持された砥粒は定盤回転速度に近 い速度で移動するため, 滑り速度が遅くなり砥粒と工作物との 相対速度が速くなるため研磨能率が向上すると考えられる. 


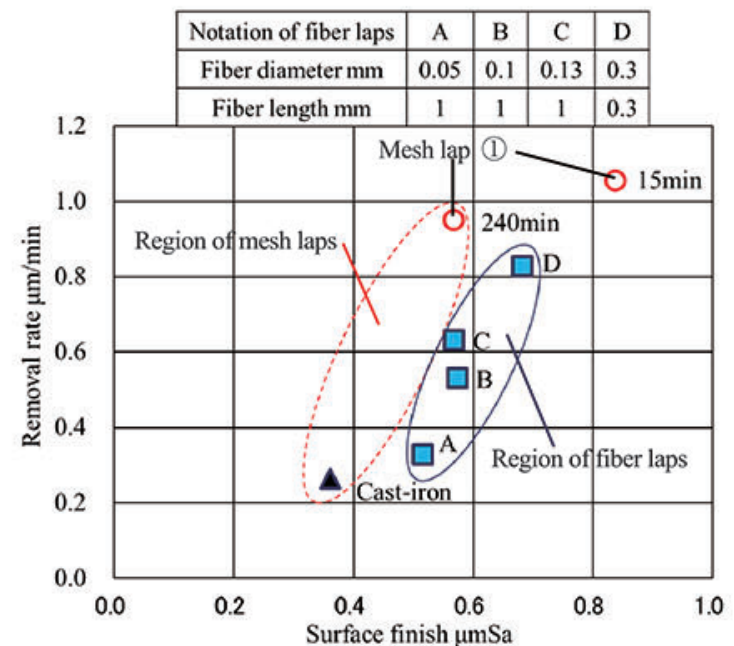

Fig.14 Relationship between surface finish and removal rate using GC\#600 abrasive grains and various lapping tools

\section{5. 織維定盤の研磨性能の向上}

\section{1 織維径による研磨性能の変化}

これまでのメッシュ工具の実験データを元に繊維定盤の 研磨性能の向上を試みた. 図 7 から研磨能率に対するワイ ヤ径とピッチ間隔の相関係数を算出した結果, ワイヤ径が 0.975，ピッチ間隔が 0.888 となり，ワイヤ径の方が相関関 係が強いことがわかった。この結果から繊維径を変更させ た纎維定盤を製作し実験を行うことにした．また繊維の含 有量は, ワイヤ径 $0.29 \mathrm{~mm}$ の 40 メッシュ工具(1)の研磨後 のワイヤ部の体積の割合が $40 \mathrm{vol} \%$ であったことから緎維 定盤も同様に $40 \mathrm{vol} \%$ とした. 繊維には, びびり振動切削で 製作が可能なステンレス鋼の長さが $1 \mathrm{~mm}$ で直径が 0.05 $\mathrm{mm}, 0.1 \mathrm{~mm}, 0.13 \mathrm{~mm}$ の 3 種類の繊維を用いた ${ }^{5)}$. メッ シュ工具で最も研磨能率が高かったワイヤ径 $0.29 \mathrm{~mm}$ の 40 メッシュ工具(1)と同じ繊維径のものはびびり振動切削では 製作が困難であったため，ステンレス鋼のワイヤで直径が $0.3 \mathrm{~mm}$ のものを $0.3 \mathrm{~mm}$ の長さで切断した既製品 (IKK シ ヨット社製)の緎維を用いた.この 4 種類の繊維定盤を用い て, 表 1 の条件で実験を行った結果を図 14 に示す. 緎維が 太くなるほど研磨能率は向上することがわかった。これは 繊維が太くなったことで砥粒のせき止め効果が高められた ためと考えられる. また繊維径が $0.3 \mathrm{~mm}$ の繊維定盤が最 も研磨能率が高くなっており,この傾向はメッシュ工具の 傾向と合致している.

次に纎維定盤の表面状態を比較するために, 研磨後の定 盤表面を前述の光学式表面形状計測装置で観察した表面画 像の高さ方向の情報をもとに 2 值化処理を行った. 図 15 (a) に繊維定盤 $\mathrm{A}$, 同図 (b) に繊維定盤 D の表面を 2 值化したも のを示す.使用した砥粒の平均粒径が $20 \mu \mathrm{m}$ であったため, 定盤の上面から $20 \mu \mathrm{m}$ の深さまでの浅い領域を白色で示し， $20 \mu \mathrm{m}$ よりも深い領域を黒色で示した. 同図 (a)の繊維定盤 A では，白色部の割合が多く黒色部が島状に存在している. 一方，同図 (b) の繊維定盤 D では，黒色部が多く白色部が岛 状に存在している.この結果から瀻維定盤 A は, パンチン グメタルのように凹部が離れて存在する表面構造となった ために研磨性能が低くなったと考えられる。一方，繊維定 盤 D は島状の凸部の周りに凹部が存在していることから， ワイヤ径 $0.29 \mathrm{~mm}$ の 40 メッシュ工具(1)と同じような表面 構造を有することでせき止め効果が高められ, 研磨能率が
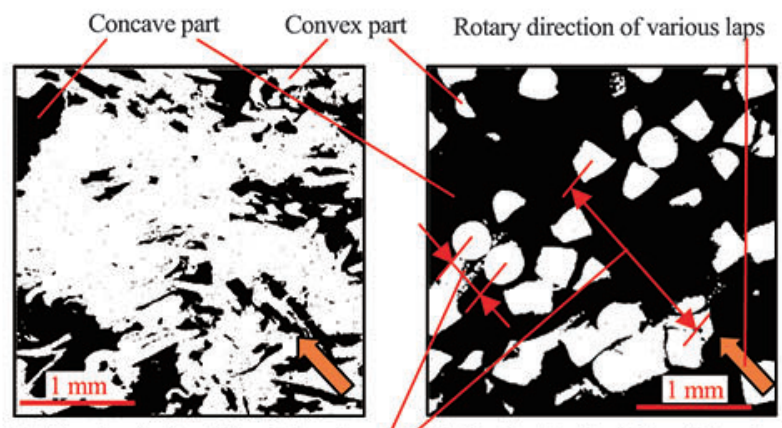

(a) Fiber lap A after 240 min lapping (b) Fiber lap D after 240 min lapping

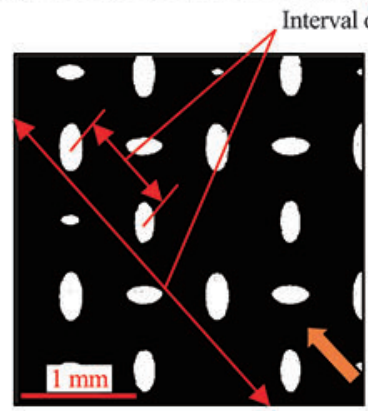

(c) Mesh lap (1) after 15 min lapping

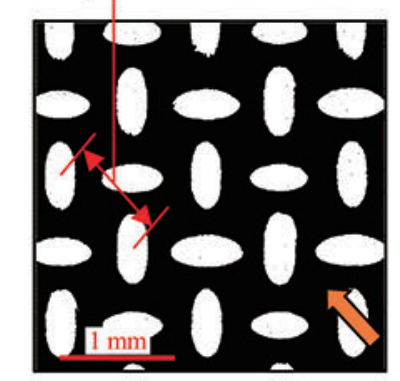

(d) Mesh lap (1) after 240 min lapping

Fig.15 Case of binarized images of high area of various lapping tools used (Zygo)

向上したと考えられる

\section{2 織維定盤での仕上げ面粗さ悪化の原因}

仕上げ面粗さを比較すると, 図 14 に示されたメッシュ工 具のプロット領域(図 7 参照)から繊維定盤の方が仕上げ面 粗さが悪化している．この原因を調べるために，図 15 と同 様にワイヤ径 $0.29 \mathrm{~mm}$ の 40 メッシュ工具(1)の 15 分研磨後 と 240 分研磨後の表面画像から 2 值化処理を行ったものを 図 15 (c) と (d)に示し, 図 14 にその研磨能率と仕上げ面粗さ を付記した. 15 分研磨後の研磨能率は研磨時間 10 分から 15 分までの 5 分間の平均值である. 図 15 にラップ工具の回 転方向のメッシュ工具(1)と繊維定盤 D の凸部の間隔を示す. 同図 (d)のメッシュ工具(1)ではワイヤ摩耗部が規則的に配 列し凸部の間隔も一定になっているが，同図 (b)の繊維定盤 D では瀻維が密になっている箇所と疎になっている箇所が あり，繊維間隔が大きく異なっている。このように瀻維の 間隔が広くなる箇所があることで作用砥粒間隔も広くなり 仕上げ面粗さがメッシュ工具よりも悪化したと考えられる. このことから繊維定盤でも，瀻維をより均一に配列するこ とができれば仕上げ面粗さを改善させることが可能である と予想される.

またワイヤ径 $0.29 \mathrm{~mm}$ の 40 メッシュ工具(1)でも図 15 (c) の 15 分研磨後ではワイヤ摩耗部が小さく, 工具回転方向の 凸部の間隔が広くなる箇所があるため, 図 14 に示されるよ うに 15 分研磨後は, 240 分研磨後に比べて仕上げ面粗さが 悪化することが確認された.

\section{6. 結言}

本研究では, 繊維定盤に含有させる瀻維形状を最適化するた めに用いたメッシュ工具が高い研磨性能を有することがわかり, その研磨メカニズムを解明することで, 瀻維定盤の研磨性能の 向上を試みた. 以下に本研究で得られた結果についてまとめる. 
(1) メッシュ工具はワイヤ径とピッチ間隔を変化させること で，研磨性能を大きく変化させることができることがわ かった.

(2) メッシュ工具はワイヤ径とピッチ間隔を変化させること で砥粒の挙動も変化し, 蛇行する砥粒と直線的に移動する 砥粒の 2 種類の砥粒の挙動があることがわかった.

(3) 蛇行する砥粒が多いメッシュ工具は, 砥粒がワイヤ摩耗部 のエッジ部にも保持されやすくなり, 相対速度が速くなる ことで研磨能率は向上する. 一方, 直線的に移動する砥粒 が多いメッシュ工具は砥粒がエッジ部に保持されにくい ため相対速度が遅くなることで研磨能率は減少する.

（4）繊維定盤は，凹部が雄れて存在する表面状態を示す場合よ りも凸部が島状に存在しその周りに凹部が存在する表面 状態を示す場合に研磨能率が向上することがわかった.

(5) 繊維定盤は最も研磨性能の高いメッシュ工具のワイヤ径
と同等の織維径を用いることで，鋳鉄定盤に比べて研磨 能率が約 3 倍に向上することがわかった.

最後に本研究の一部は, 滋賀県中小企業新技術開発プロジ エクト補助金の補助を受けて行われたことを報告し, 関係各 位にここに深く謝意を表します.

\section{参 考 文 献}

1) 藤平龍彦, 宝泉徽, 栗原俊治 : パワー半導体の現状と展望, 富士電機 技報, 89, 4 (2016) 226 .

2) 加藤智久 : NEDO プロ「低酸素社会を実現する新材料パワー半導体 プロジェクト」での大口径 SiC ウェハ加工技術開発, 精密工学会誌, 80, 1 (2014) 18

3) 谷泰弘 : 研磨工具は未知の世界, 精密工学会誌, 81, 12 (2015) 1078.

4) 川波多裕司, 桐野宙治, 張宇, 谷泰弘 : 金属短繊維含有ラップ工具の 開発，精密工学会誌，83，7(2017) 672.

5) 鈴木清, 植松哲太郎, 中川威雄 : びびり振動切削における瀻維製造領 域, 精密工学会誌, 53，6(1987) 921 . 